May 2002 • NREL/CP-520-31405

\title{
What is the Appropriate Reference Spectrum for Characterizing Concentrator Cells?
}

\section{Preprint}

K. Emery, D. Myers, and S. Kurtz

To be presented at the $29^{\text {th }}$ IEEE PV Specialists Conference

New Orleans, Louisiana

May 20-24, 2002

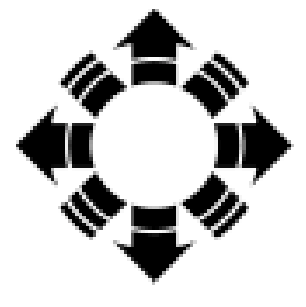

\section{NPEI}

National Renewable Energy Laboratory

1617 Cole Boulevard

Golden, Colorado 80401-3393

NREL is a U.S. Department of Energy Laboratory

Operated by Midwest Research Institute $\bullet$ Battelle $\bullet$ Bechtel

Contract No. DE-AC36-99-G010337 


\section{NOTICE}

The submitted manuscript has been offered by an employee of the Midwest Research Institute (MRI), a contractor of the US Government under Contract No. DE-AC36-99G010337. Accordingly, the US Government and MRI retain a nonexclusive royalty-free license to publish or reproduce the published form of this contribution, or allow others to do so, for US Government purposes.

This report was prepared as an account of work sponsored by an agency of the United States government. Neither the United States government nor any agency thereof, nor any of their employees, makes any warranty, express or implied, or assumes any legal liability or responsibility for the accuracy, completeness, or usefulness of any information, apparatus, product, or process disclosed, or represents that its use would not infringe privately owned rights. Reference herein to any specific commercial product, process, or service by trade name, trademark, manufacturer, or otherwise does not necessarily constitute or imply its endorsement, recommendation, or favoring by the United States government or any agency thereof. The views and opinions of authors expressed herein do not necessarily state or reflect those of the United States government or any agency thereof.

Available electronically at http://www.osti.gov/bridge

Available for a processing fee to U.S. Department of Energy and its contractors, in paper, from:

U.S. Department of Energy

Office of Scientific and Technical Information

P.O. Box 62

Oak Ridge, TN 37831-0062

phone: 865.576 .8401

fax: 865.576.5728

email: reports@adonis.osti.gov

Available for sale to the public, in paper, from:

U.S. Department of Commerce

National Technical Information Service

5285 Port Royal Road

Springfield, VA 22161

phone: 800.553 .6847

fax: 703.605.6900

email: orders@ntis.fedworld.gov

online ordering: http://www.ntis.gov/ordering.htm

Printed on paper containing at least $50 \%$ wastepaper, including $20 \%$ postconsumer waste 


\title{
WHAT IS THE APPROPRIATE REFERENCE SPECTRUM FOR CHARACTERIZING CONCENTRATOR CELLS?
}

\author{
Keith Emery, Daryl Myers, and Sarah Kurtz \\ National Renewable Energy Laboratory (NREL), 1617 Cole Blvd., Golden, CO 80401
}

\begin{abstract}
Consensus standards for determining the efficiency of a concentrator cell or module have not been developed. NREL, Sandia National Laboratory, the Fraunhofer Institute for Solar Energy in Germany, and the Progress in Photovoltaics Efficiency Table authors have informally agreed upon concentrator-cell reference conditions. These conditions are $25^{\circ} \mathrm{C}$ cell temperature, 1 -sun $=1000 \mathrm{~W} / \mathrm{m}^{2}$ total irradiance, and the ASTM E891-87 direct-normal reference spectrum. Deficiencies in the direct reference spectrum are discussed, and a more representative reference spectrum for evaluating concentrator cells is proposed. The spectrum was generated by the SMARTS model, and the atmospheric parameters are as close as possible to the existing direct spectrum, with the exception that the aerosol optical depth at $500 \mathrm{~nm}$ is reduced from 0.27 to 0.085 .
\end{abstract}

\section{REVIEW OF EXISTING REFERENCE CONDITIONS}

Consensus standards were first proposed at the first and second terrestrial Photovoltaic Measurement Procedures Workshop in 1976 and documented in the Terrestrial PV Measurements Procedures [1-3]. The manual specified equipment and procedures for measurement of light I-V curves for one-sun and concentrator cells and modules [3]. For measurement of concentrator cells, the manual specified a direct-beam reference spectrum, a one-sun irradiance of $1000 \mathrm{~W} / \mathrm{m}^{2}$, a temperature of $28^{\circ} \mathrm{C}$, and an area defined as the area that is designed to be illuminated, which is normally the total area minus any peripheral bus bars or contacts [3]. For concentrator modules, the area was taken to be the cross-sectional area of the lens or mirror receiver. For the direct-beam reference spectrum, the atmospheric parameters were $2 \mathrm{~cm}$ precipitable water vapor, a turbidity of 0.12 , an air mass (AM) of 1.5 , and $0.34 \mathrm{~cm}$ of ozone [3]. The 1977 model was rather crude and was regenerated for global and direct conditions using a Monte Carlo computer model [4]. This new rigorous model was based on the United States Standard Atmosphere Mid-Latitude Summer profile, with $1.416 \mathrm{~cm}$ of precipitable water vapor and an ozone level of 0.344 . An air mass of 1.5 at sea level with a sun-facing surface tilted at $37^{\circ}$ and a wavelength-independent ground reflectivity of 0.2 were chosen [4].

The simplistic aerosol profile in the original reference spectrum [3] was difficult to reproduce and contained several errors in implementation. A rural aerosol profile was chosen in the rigorous model, and it corresponded to an aerosol optical depth at $500 \mathrm{~nm}$ of 0.27 or a visibility of $23 \mathrm{~km}$. The choice of 0.27 for the turbidity was based on limited resource information, but was intended to be an average value in the continental United States and not an average value in locations where concentrators might be deployed. The results from the Monte Carlo model in Reference 4, along with the data from an undocumented simple model, were then incorporated into standards [5-7]. These standards have been in use by the photovoltaics community since about 1985.

Reference conditions for rating concentrator cells and modules have been informally agreed upon by NREL, Sandia National Laboratory, the Fraunhofer Institute for Solar Energy in Germany, and the Progress in Photovoltaics Efficiency Table authors [8]. These conditions are $25^{\circ} \mathrm{C}$ cell temperature, one-sun $=1000 \mathrm{~W} / \mathrm{m}^{2}$ total irradiance, and the ASTM E891-87 direct-normal reference spectrum in Reference 7. Concentrator modules and systems have been rated at PVUSA with respect to their performance at a directnormal irradiance of $850 \mathrm{~W} / \mathrm{m}^{2}, 1 \mathrm{~m} / \mathrm{s}$ wind speed, and an air temperature of $20^{\circ} \mathrm{C}$ [9]. Consensus standards for concentrator measurements are currently under development in the United States and Europe.

\section{MOTIVATION FOR CHANGING DIRECT REFERENCE SPECTRUM}

The U.S. Department of Energy (DOE) HighPerformance PV Project calls for a $33 \%$ concentrator module and a $40 \%$ concentrator cell to be developed [10]. The reference conditions to be used for measuring these efficiencies need to be clearly defined.

Recent work has shown that the direct reference spectrum is not representative of sunny conditions in regions with a high annual direct-normal energy where concentrators might be deployed (the Sun Belt). In the past, this issue did not matter because at a given total irradiance and cell temperature under direct, global, or clear-sky natural sunlight, concentrator PV cells or modules produced the same shortcircuit current within $\pm 2 \%$. The reason stems from the fact that in the past, the only concentrator cells were singlejunction $\mathrm{Si}, \mathrm{GaAs}$, or independently measured multijunction cells that have a small spectra sensitivity. In contrast, the short-circuit current of the series-connected GalnP/GaAs/ Ge triple-junction cells are much more sensitive to spectral variations. The highest efficiency cell measured at NREL was $34.0 \pm 1.5 \%$ for solar fluxes between about 130 and 630 suns under the IEC global reference spectrum [5,6] and 
$30.7 \pm 1.5 \%$ under the ASTM E891-87 direct reference spectrum [7]. Reference conditions should provide a basis for optimizing energy production of cells in the field. A recent study using standard reference days shows that GalnP/GaAs cells optimized for the direct spectrum produce $1 \%$ to $3 \%$ less electricity than cells optimized for daily energy [11]. The direct spectrum predicts $7 \%$ less power at solar noon for the hot-sunny reference day compared with $1 \%$ for the global spectrum [11].

This sensitivity to spectrum becomes problematic if the indoor measurement spectrum differs significantly from the spectra that are typically observed outdoors. The PVUSA procedure for outdoor characterization of concentrator modules has no provisions for correction to a given reference spectrum. This means that concentrator modules evaluated at direct irradiances greater than $850 \mathrm{~W} / \mathrm{m}^{2}$ are being rated under conditions more representative of the IEC global spectrum or the direct spectrum with a more representative turbidity. Most of the test locations for concentrator modules encounter direct spectra that are substantially different from the existing direct reference spectrum.

Changing standard reference conditions is problematic and should not be taken lightly. In the early 1980s, there were a wide range of "AM1.5" spectra that various groups around the world referred to, giving a spread in short-circuit currents of $3 \%$ to $9 \%$, depending on the spectra and $\mathrm{PV}$ technology [12]. The world is now in agreement for the standard reference spectra for evaluating nonconcentrating cells and modules at the national (U.S., Japanese, and European Commission standards) and international (IEC standards) level. This is not the case for concentrators.

This paper discusses the technical basis for the new proposed direct reference spectrum and its effect on the short-circuit current. NREL will adopt this spectrum for evaluating concentrator cells and submit it to various standards organizations for consideration.

\section{SELECTION OF DIRECT-BEAM REFERENCE CONDITIONS}

The justification for AM1.5 as the appropriate air mass for rating concentrator performance has never been published. Figure 1 shows that $50 \%$ of the direct-beam annual energy derived from the TMY2 data base is delivered at an absolute (pressure-corrected) air mass of 1.5 for many locations [13]. This validates the choice of AM1.5 as the reference air mass. Note that sunny locations such as Boulder, Colorado or Albuquerque, New Mexico have 20\% of the direct beam energy delivered at an absolute or pressure-corrected air mass less than 1.

Current aerosol information is more comprehensive and more accurate than the information used in the BRITE comprehensive computer model to generate the current reference spectra $[14,15]$. Figure 2 shows the region of the United States that was selected to determine the average turbidity to use in modeling the proposed direct reference spectrum. Sites in the continental United States with a daily direct beam energy greater than $6 \mathrm{kWh} / \mathrm{m}^{2} /$ day were selected. In Table 1 the aerosols for the selected sites used to arrive at a broadband aerosol optical depth of 0.0565 are given. The aerosol optical depth at $500 \mathrm{~nm}$ is required for spectral modeling purposes and was determined using the procedure described in Reference 15.

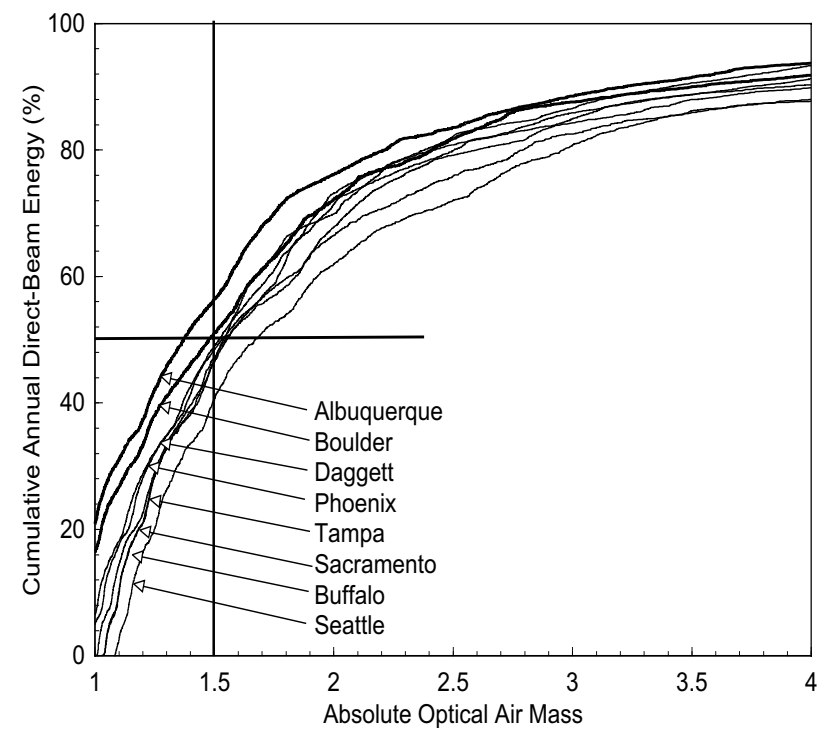

Fig. 1. Cumulative annual direct-beam energy from TMY2 data base. Note that for Colorado and New Mexico, 20\% of the energy is delivered below air mass 1 .

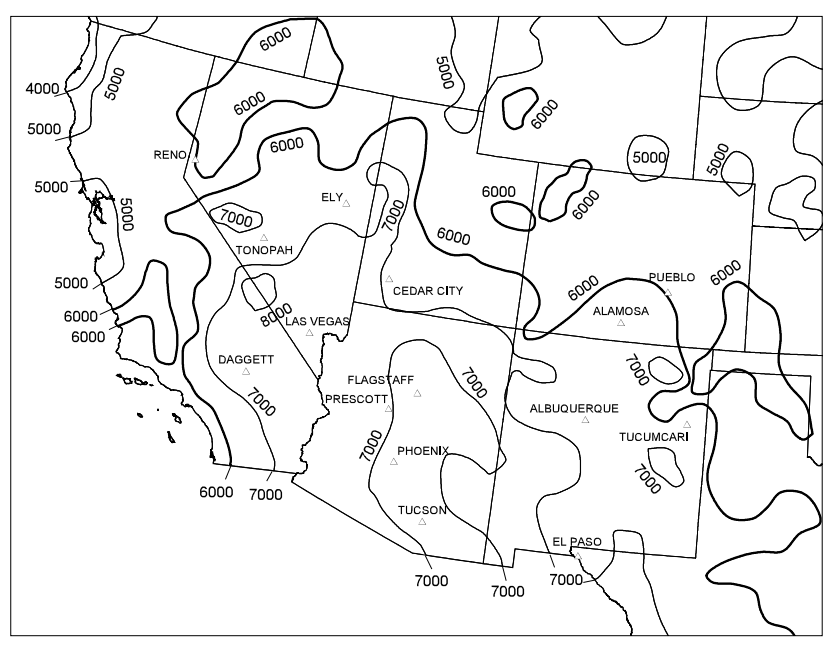

Fig. 2. Region of the United States where the average daily direct-beam energy is greater than $6 \mathrm{kWh} / \mathrm{m}^{2} /$ day has an average broadband aerosol optical depth of 0.0565 , corresponding to an aerosol optical depth at $500 \mathrm{~nm}$ or turbidity of 0.085 . 
Table 1. Sites used to determine the average aerosol optical depth in the sunbelt $[14,15]$. Data was collected at the prime sites and modeled using the METSTAT model [15].

\begin{tabular}{|c|c|c|c|c|}
\hline $\begin{array}{l}\text { AOD } \\
@ 500 \text { nm }\end{array}$ & $\begin{array}{l}\text { AOD } \\
\text { broad be }\end{array}$ & d Station & $\underset{\mathrm{kWh} / \mathrm{m}^{2} / \mathrm{d}}{\mathrm{E}_{\mathrm{tot}}}$ & type \\
\hline 0.087 & 0.058 & Daggett, CA & 7.50 & prime \\
\hline 105 & 0.068 & Las Vegas, NV & 7.10 & prime \\
\hline 099 & 0.065 & Tucson, AZ & 7.00 & prime \\
\hline 0.142 & 0.090 & Phoenix, AZ & 6.80 & prime \\
\hline 074 & 0.050 & Prescott, AZ & 6.80 & mode \\
\hline .029 & 0.024 & Alamc & 6.80 & prime \\
\hline .074 & 0.050 & Albuquerque, NM & 6.70 & prime \\
\hline 0.082 & 0.055 & Tonopah, NV & 6.70 & mode \\
\hline 118 & 0.076 & EI P & 6.70 & prime \\
\hline .074 & 0.050 & Flagstaff, AZ & 6.40 & mode \\
\hline 0.091 & 0.060 & Reno, NV & 6.20 & mode \\
\hline 074 & 0.050 & Cedar City, UT & 6.20 & mode \\
\hline 1 & 0.050 & Puebl & 6.10 & mode \\
\hline 0.099 & 0.065 & Tucumcari, NM & 6.10 & mode \\
\hline 0.050 & $\underline{0.036}$ & Ely, NV & 6.00 & prime \\
\hline
\end{tabular}

A comprehensive computer model was used to generate the revised spectrum and has been compared against other comprehensive models [16-18]. Figure 3 compares the existing global and direct reference spectra with the proposed direct spectrum. The proposed direct spectrum uses the same meteorological parameters as the existing reference spectra but with the lower aerosol optical depth of 0.085 at $500 \mathrm{~nm}$. Figure 4 shows the percentage variation in the short-circuit current for the proposed direct spectrum, the existing direct spectrum, and the proposed global reference spectrum, compared with the existing global reference spectrum. The quantum efficiencies used in calculating the short-circuit current densities in Figure 4 are given in Figures 5 and 6 . As expected, the variation for single-junction devices is much less than the variation for multijunction devices. The global spectrum corresponding to the proposed direct spectrum affects the short-circuit current for all relevant PV technologies less than $\pm 1 \%$ compared to the existing global reference spectrum.

\section{SUMMARY}

The justification for rating concentrator cells at an aerosol optical depth (AOD) typical of the sunbelt instead of the 0.27 AOD at $500 \mathrm{~nm}$ is given. The corresponding direct spectrum is more realistic for optimizing concentrator modules for maximum energy production over the entire day, and especially near solar noon, based on modeling work presented elsewhere at this conference [11]. The spectrum can be obtained by sending an email to keith_emery@nrel.gov. Procedures for evaluating concentrator modules have not been standardized and are an active area of research. In the meantime, procedures for rating concentrator modules will follow procedures developed by PVUSA, Sandia, and other groups.

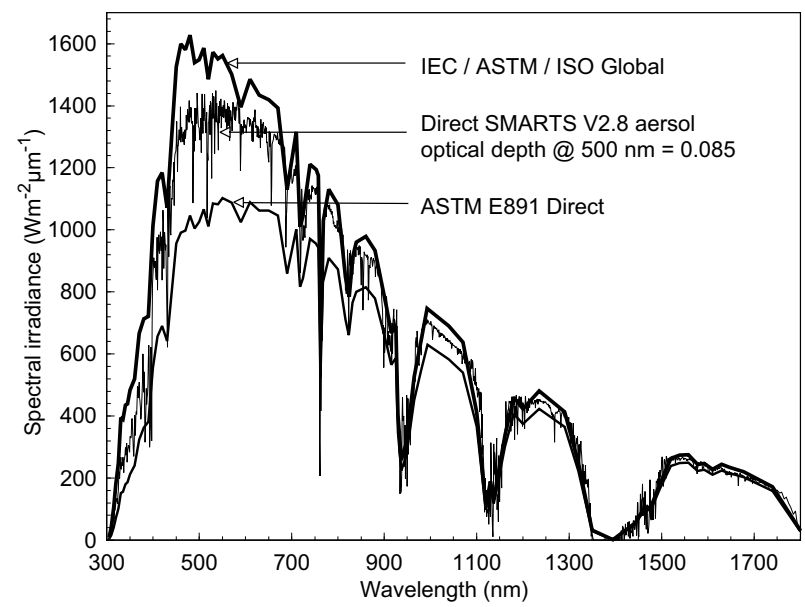

Fig. 3. Proposed direct reference spectrum compared with the current global and direct reference spectra.

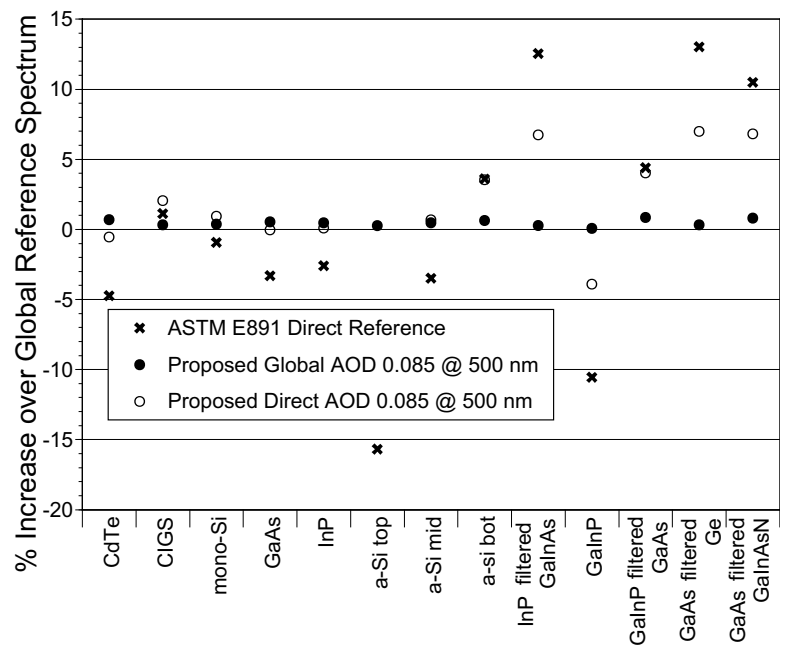

Fig. 4. Percentage change in the normalized short-circuit current from the normalized global reference spectrum for various state-of-the-art PV technologies compared with the proposed direct reference spectra.

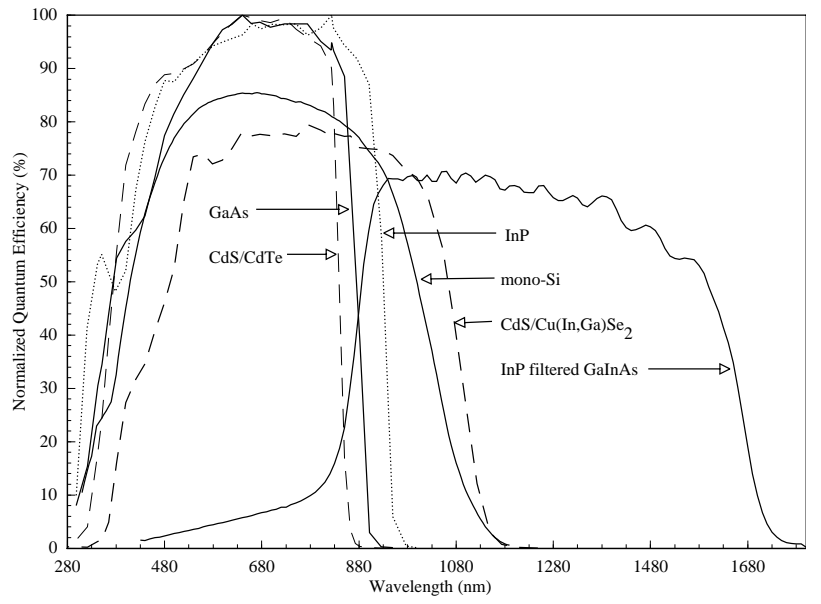

Fig. 5. Quantum efficiencies used for six of the PV technologies in Figure 4. 


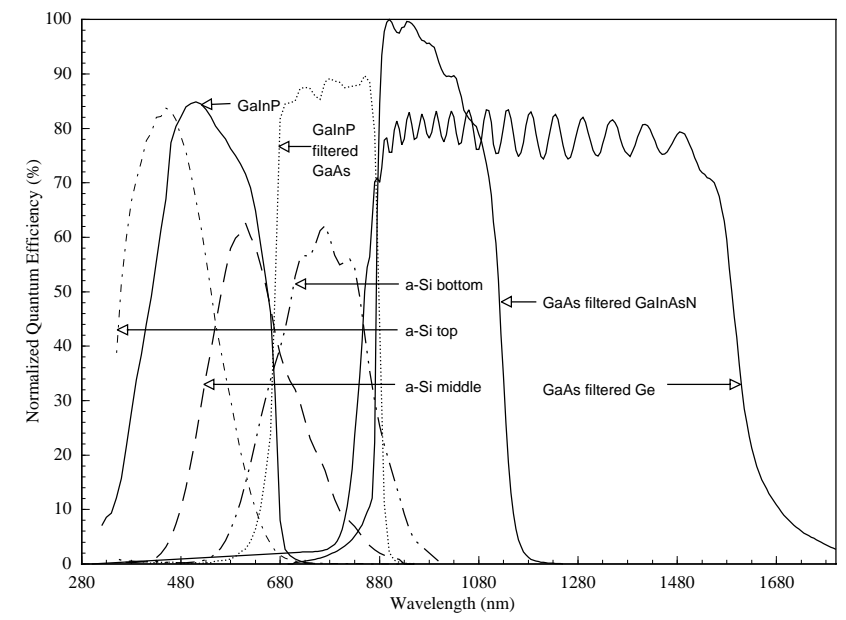

Fig. 6. Quantum efficiencies used in calculating the shortcircuit current densities for the remaining seven PV technologies in Figure 4.

\section{ACKNOWLEDGEMENTS}

This work was supported in part under DOE Contract DE-AC36-99G010337. The authors also wish to acknowledge the encouragement of R. Hulstrom and M. SymkoDavis. The assistance of D. Heimiller in producing the resource maps and of M. Forest and D. Gwinner for editing is acknowledged.

\section{REFERENCES}

[1] Terrestrial Photovoltaic Measurements Workshop Proceedings, Cleveland, OH, March 15-21, 1975, L. Scuddre and T. Klucher editors, NASA tech. rep. TM X-71802.

[2] Terrestrial Photovoltaic Measurements Workshop Proceedings, Baton Rouge, LA, Nov. 10-12, 1976, ERDA/NASA1022/76/10.

[3] Terrestrial Photovoltaic Measurement Procedures, NASA Tech. Report TM 73702, June 1977.

[4] R.E. Bird, R.L. Hulstrom, and L.J. Lewis, (1983), "Terrestrial Solar Spectral Data Sets," Solar Energy, 39, p. 563.

[5] Standard IEC 60904-3, Measurement Principles for Terrestrial PV Solar Devices with Reference Spectral Irradiance Data, International Electrotechnical Commission, (1989), Geneva, Switzerland.

[6] Standard ASTM E892-92, Standard for Terrestrial Solar Spectral Irradiance Tables at Air Mass 1.5 for a $37^{\circ}$ Tilted Surface, Amer. Society for Testing Matls., West Conshocken, PA, USA.

[7] Standard ASTM E891-92, Standard for Terrestrial Solar Direct Normal Solar Spectral Irradiance Tables for Air Mass 1.5, Amer. Society for Testing Matls., West Conshocken, PA, USA.
[8] M.A. Green and K. Emery, D.L. King, S. Igari, and W. Warta, "Solar Cell Efficiency Tables (version 19)," Progress in PV Research and Applications, vol. 10, p. 55, 2002.

[9] S.L. Hester, T.U. Townsend, W.T. Clements, and W.J. Stolte, (1990), PVUSA: Lessons Learned from Startup and Early Operation, Proceedings of the 21st IEEE PV Specialists Conf., Orlando, pp. 937.

[10] M. Symko-Davis, R. Noufi, and S. Kurtz, "Identifying Critical Pathways for High-Performance PV," this conference.

[11] W. E. McMahon, S. Kurtz, K. Emery, and M. Young, "Criteria for the Design of GalnP/GaAs Tandem Cells, to Optimize Their Performance Outdoors," this conference.

[12] N.M. Pearsall, K.A. Emery, and M. Davies, "Influence of Reference Cell and Spectrum on the Measurement of Solar Cells," Proc. 7th Eur. PV Solar Energy Conf., Oct. 2731,1986, p. 298.

[13] W. Marion and K. Urban, 'Users' Manual for TMY2s (Typical Meteorological Years)-Derived from the 1961-1990 National Solar Radiation Database, NTIS/GPO number: DE950040604," National Renewable Energy Laboratory, Golden, Technical TP-463-7688, 1995.

[14] E.L. Maxwell, W. Marion, D. Myers, M. Rymes, and S. Wilcox, "Final Technical Report - National Solar Radiation DataBase (1961-1990)," National Renewable Energy Laboratory, Golden, CO, NREL/TP-463-5784, 1995.

[15] E.L. Maxwell, (1998). "METSTAT The Solar Radiation Model Used in the Production of the National Solar Radiation DataBase (NSRDB)." Solar Energy 62(4): 263-279.

[16] Gueymard, C. (2001). "Parameterized Transmittance Model for Direct Beam and Circumsolar Spectral Irradiance." Solar Energy 71(5): 325-346.

[17] D. Myers, K. Emery, and C. Gueymard, "Proposed Reference Spectral Irradiance Standards to Improve Photovoltaic Concentrating System Design and Performance Evaluation," this conference.

[18] D. Myers and K. Emery, "Terrestrial Solar Spectral Modeling Tools and Applications for Photovoltaic Devices," this conference. 


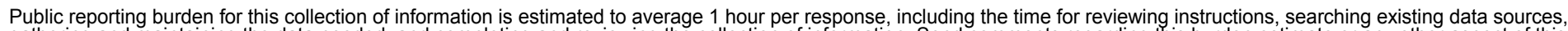

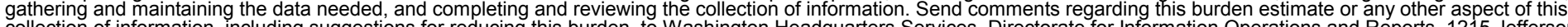
Davis Highway, Suite 1204, Arlington, VA 22202-4302, and to the Office of Management and Budget, Paperwork Reduction Project (0704-0188), Washington, DC 20503.

\begin{tabular}{|l|l|l}
\hline 1. AGENCY USE ONLY (Leave blank) & $\begin{array}{l}\text { 2. REPORT DATE } \\
\text { May } 2002\end{array}$ & $\begin{array}{l}\text { 3. REPORT TYPE AND DATES COVERED } \\
29^{\text {th }} \\
\text { IEEE PVSC-Conference Paper } \\
\text { May 20-24, 2002 }\end{array}$ \\
\hline
\end{tabular}

4. TITLE AND SUBTITLE

What Is The Appropriate Reference Spectrum For Characterizing Concentrator Cells?:

Preprint
5. FUNDING NUMBERS PVP23401

6. $\operatorname{AUTHOR}(\mathrm{S})$

K. Emery, D. Myers, and S. Kurtz

7. PERFORMING ORGANIZATION NAME(S) AND ADDRESS(ES)

National Renewable Energy Laboratory

8. PERFORMING ORGANIZATION REPORT NUMBER

1617 Cole Blvd.

Golden, CO 80401-3393

9. SPONSORING/MONITORING AGENCY NAME(S) AND ADDRESS(ES)

National Renewable Energy Laboratory

1617 Cole Blvd.

Golden, CO 80401-3393

10. SPONSORING/MONITORING AGENCY REPORT NUMBER

NREL/CP-520-31405

11. SUPPLEMENTARY NOTES

12a. DISTRIBUTION/AVAILABILITY STATEMENT

National Technical Information Service

12b. DISTRIBUTION CODE

U.S. Department of Commerce

5285 Port Royal Road

Springfield, VA 22161

13. ABSTRACT (Maximum 200 words) This conference paper describes Consensus standards for determining the efficiency of a concentrator cell or module that have not been developed. NREL, Sandia National Laboratory, the Fraunhofer Institute for Solar Energy in Germany, and the Progress in Photovoltaics Efficiency Table authors have informally agreed upon concentrator-cell reference conditions. These conditions are $25^{\circ} \mathrm{C}$ cell temperature, $1-\mathrm{sun}=1000 \mathrm{~W} / \mathrm{m} 2 \mathrm{total}$ irradiance, and the ASTM E891-87 direct-normal reference spectrum. Deficiencies in the direct reference spectrum are discussed, and a more representative reference spectrum for evaluating concentrator cells is proposed. The spectrum was generated by the SMARTS model, and the atmospheric parameters are as close as possible to the existing direct spectrum, with the exception that the aerosol optical depth at $500 \mathrm{~nm}$ is reduced from 0.27 to 0.085 .

14. SUBJECT TERMS: PV; concentrator cell; module; cell temperature; direct-beam reference spectrum; one-sun irradiance; aerosol optical depth; short -circuit current; global reference spectrum; multijunction devices;

17. SECURITY CLASSIFICATION OF REPORT Unclassified
18. SECURITY CLASSIFICATION OF THIS PAGE Unclassified
19. SECURITY CLASSIFICATION OF ABSTRACT

Unclassified
15. NUMBER OF PAGES

16. PRICE CODE UL 